\title{
Poorly differentiated oesophageal squamous cell carcinoma in Western Kenya: A case report
}

\author{
Author: \\ Masemiano P. Chege ${ }^{1}$ \\ Affiliation: \\ ${ }^{1}$ Department of family \\ Medicine, Moi University \\ School of Medicine, Kenya \\ Correspondence to: \\ Masemiano Chege \\ Email: \\ chege200851@yahoo.com \\ Postal address: \\ PO Box 4606, Eldoret 30100 , \\ Kenya \\ Dates: \\ Received: 08 Oct. 2010 \\ Accepted: 06 Dec. 2010 \\ Published: 14 July 2011 \\ How to cite this article: \\ Chege, MP. Poorly \\ differentiated oesophageal \\ squamous cell carcinoma \\ in Western Kenya: A case \\ report. Afr J Prm Health Care \\ Fam Med. 2011;3(1), Art. \\ \#236, 3 pages. doi:10.4102/ \\ phcfm.v3i1.236
}

C 2011. The Authors. Licensee: OpenJournals Publishing. This work is licensed under the Creative Commons Attribution License.

\section{Introduction}

Cancer of the oesophagus is the eighth (some articles put it as sixth) most common cancer in the world. Squamous cell carcinoma is the predominant histological type with the highest incidence in the 'Asian oesophageal cancer belt'. ${ }^{1}$ A recent study documented the unusual findings of oesophageal cancer in young Kenyans from Western Kenya and suspected genetic or familial risk factors could be involved. ${ }^{2}$ The suspected genetic risk has been documented in studies conducted in Asia where the condition is prevalent. ${ }^{3,4,5,6,7,8}$

Patients with oesophageal cancer tend to present to rural hospitals in sub-Saharan Africa when it is too late (usually when the advanced disease has made it difficult for them to swallow even saliva). The outcomes of care are limited by the late presentation, unavailability of diagnostic and healthcare resources in these rural district hospitals and poverty in amongst local people. In most cases all we can do is a barium swallow to strengthen our clinical suspicion, because endoscopic and histology services are located far from these hospitals. Those patients that can afford the histology will, in nearly all cases, find it difficult to pursue further specialised care. This implies that the clinical suspicion of oesophageal cancer in these facilities translates to certain death within weeks. Consequently, we would like to present this case and compile a literature review on risk factors for oesophageal squamous cell carcinoma (OSCC) to highlight this dilemma. We also want to demonstrate our limitations in managing this severe disease which affects young patients who do not seem to have been exposed to the traditionally cited risk factors in other parts of the world where oesophageal carcinoma is prevalent.

\section{Ethical considerations}

The ethical consideration for this case report was approved by Moi University Institutional Research Ethics Committee (IREC) and the administration Webuye district hospital where the patient was managed.

\section{Case report}

A 17-year-old girl presented with progressive difficulty in swallowing which was associated with retrosternal pain and progressive wasting over a two month period, in our regional (provincial) hospital. She also reported coughing productive and that was occasionally blood stained.

Swallowing was not painful but initially she had trouble swallowing solid food and had the sensation that the food was lodged in her 'chest'. This was followed by a progressive regurgitation of solids and finally liquids, including saliva, within a period of eight weeks.

There was no history of fever or night sweats. None of her family members was infected with tuberculosis at present or had been diagnosed with tuberculosis in the recent past. Her health history was insignificant. She was the third in a family of five siblings. All the other siblings and her parents were in good health. There was no family history of cancer or chronic noncommunicable disease.

When she was admitted to our hospital, she was already being treated for pulmonary tuberculosis with the diagnosis based on a chest x-ray examination in the regional hospital.

On examination she was found to be severely wasted and dehydrated, but without fever or enlarged superficial lymph nodes. The other significant clinical findings were of left sided pleural effusion.

A repeat chest x-ray confirmed the pleural effusion which was found to be straw coloured on tapping, with a high protein but insignificant white cell count. The full haemogram, renal and liver function tests were normal. A diagnosis of a possible oesophageal fistula was entertained 
and she was referred for an upper gastrointestinal tract endoscopy, 80 kilometres away.

The endoscopy revealed that she had a fungating obstructive mass at a position of 20 centimetres from the top of the oesophagus that did not allow further advancement of the scope. A biopsy was taken which histology showed poorly differentiated squamous cell carcinoma.

The patient and her parents were well briefed about the endoscopic and histology findings and the patient was registered for palliative care. The possibility of palliative stenting of the mass in a missionary hospital 350 kilometres away was discussed with the family but they declined because of financial constraints. The parents opted to nurse her at home with support from our palliative care team. Her condition continued to deteriorate and she died at home two weeks after the diagnosis was confirmed.

\section{Discussion}

Heavy smoking and alcohol consumption (over an extended period of time) are well documented risk factors for oesophageal squamous cell carcinoma (OSCC). $9,10,11,12,13,14,15,1$ $6,17,18,19$ A diet that is high in cholesterol, refined sugars, but low in fibre and fruit has been associated with an increased incidence of OSCC..$^{20}$ Pickled vegetables, commonly ingested in Asia, has been associated with an increased incidence of oesophageal cancer. ${ }^{21}$ Some studies have documented an association of Human Papilloma Virus (HPV) infection with an increased incidence of oesophageal cancer..$^{22,23}$

In Kenya oesophageal cancer is geographically unevenly distributed with a high incidence in very specific districts that are erratically spread. A study in the regional hospital for Western Kenya rated oesophageal cancer as the most common male malignancy and the third most common female malignancy in that region. ${ }^{24}$ The study documented the mean age for this condition as 58.7 years and more than $90 \%$ of the cases concerned squamous cell carcinoma. A male-to-female ratio of 1.5:1 was documented. Risk factors for the condition were not studied.

A higher prevalence of OSCC in male patients has been documented in many studies and this may not be unexpected because the prevalence of heavy smoking and drinking is higher in men than in women in the areas with the highest prevalence of the condition. There has been speculation on the possibility of the protective role of oestrogen. ${ }^{25}$

In this case we conducted a thorough history on the patient's health, her family's socio-economic status, and her dietary habits from the time she was born. We enquired about the environment where she was born and brought up. This did not reveal risk factors for OSCC. We do, however, acknowledge our limitation in how far our work-up could go, as well as the degree of curative support we could offer in our rural district hospital in Kenya.

\section{Conclusion}

The occurrence of oesophageal cancer in young people in this part of Kenya is a wake-up call for workers in healthcare, public health and pathology to work together to research and identify risk factors that could explain the early onset of OSCC. This will provide information for the Public Health Policy and Planning to devise ways of managing modifiable risk factors, the promotion of health and developing methods for early detection as well as improving management outcomes.

\section{Acknowledgments}

I would like to acknowledge David Omoit, the Webuye district hospital's Head of Medical Records for his cooperation during the study, as well as Dr Victor Buckwalter and the Webuye hospital palliative care team for their support during the management of this patient.

\section{References}

1. Szumilo J. Epidemiology and risk factors of the esophageal squamous cell carcinoma. Pol Merkur Lekarski. 2009;26(151):82-85.

2. Parker RK, Dawsey SM, Abnet CC, White RE. Frequent occurrence of esophageal cancer in young people in Western Kenya. Dis Esophagus. 2010;23(2):128-135. doi:10.1111/j.1442-2050.2009.00977.x, PMid:19473205

3. Malik MA, Upadhyay R, Modi DR, Zargar SA, Mittal B. Association of NAT2 gene polymorphisms with susceptibility to esophageal and gastric cancers in the Kashmir Valley. Arch Med Res. 2009;40(5):416-423. doi:10.1016/j. arcmed.2009.06.009, PMid:19766908

4. Zhai XD, Mo YN, Xue XQ, Zhao GS, Gao LB, Ai HW, et al. XRCC1 codon 280 and ERCC2 codon 751 polymorphisms and risk of esophageal squamous cell carcinoma in a Chinese population. Bull Cancer. 2009;96(10):E61-E65.

5. Vallbohmer D, Brabender J, Metzger R, Holscher AH. Genetics in the pathogenesis of esophageal cancer: possible predictive and prognostic factors. J Gastrointest Surg. 2010;14 Suppl 1:S75-S80. doi:10.1007/s11605-009-1021-5, PMid:19756878

6. Gao Y, Hu N, Han X, Giffen C, Ding T, Goldstein A, et al. Family history of cancer and risk for esophageal and gastric cancer in Shanxi, China. BMC Cancer. 2009;9:269. doi:10.1186/1471-2407-9-269, PMid:19656375,PMCid:2729777

7. Li Y, Sun DL, Duan YN, Zhang XJ, Wang N, Zhou RM, et al. Association of functional polymorphisms in MMPs genes with gastric cardia adenocarcinoma and esophageal squamous cell carcinoma in high incidence region of North China. Mol Biol Rep. 2010;37(1):197-205. doi:10.1007/s11033-009-9593-4, PMid:19562509

8. Zhang W, Chen X, Luo A, Lin D, Tan W, Liu Z. Genetic variants of C1orf10 and risk of esophageal squamous cell carcinoma in a Chinese population. Cancer Sci. 2009;100(9):1695-1700. doi:10.1111/j.1349-7006.2009.01240.x, PMid:19558548

9. Pandeya N, Williams GM, Sadhegi S, Green AC, Webb PM, Whiteman DC Associations of duration, intensity, and quantity of smoking with adenocarcinoma and squamous cell carcinoma of the esophagus. Am J Epidemiol. 2008;168(1):105114.doi:10.1093/aje/kwn091, PMid:18483122

10. Pandeya N, Williams GM, Green AC, Webb PM, Whiteman DC. Do low control response rates always affect the findings? Assessments of smoking and obesity in two Australian case-control studies of cancer. Aust $\mathrm{N} Z \mathrm{~J}$ Public Health. 2009;33(4):312-319.doi:10.1111/j.1753-6405.2009.00401.x, PMid:19689590

11. Antonsson A, Nancarrow DJ, Brown IS, Green AC, Drew PA, Watson DI, et al. High-risk human papillomavirus in esophageal squamous cell carcinoma. Cancer Epidemiol Biomarkers Prev. 2010;19(8):2080-2087.doi:10.1158/1055-9965.EPI10-0033

12. Huang $Y$, Chang $X$, Lee J, Cho $Y G$, Zhong $X$, Park IS, et al. Cigarette smoke induced promoter methylation of single-strand DNA-binding protein 2 in human esophageal squamous cell carcinoma. Int J Cancer. $2010 \mathrm{Jul} 23$.

13. Chung CS, Lee YC, Wang CP, Ko JY, Wang WL, Wu MS, et al. Secondary prevention of esophageal squamous cell carcinoma in areas where smoking, alcohol, and betel quid chewing are prevalent. J Formos Med Assoc. 2010;109(6):408-421. doi:10.1016/S0929-6646(10)60072-1

14. Tai SY, Wu IC, Wu DC, Su HJ, Huang JL, Tsai HJ, et al. Cigarette smoking and alcohol drinking and esophageal cancer risk in Taiwanese women. World J Gastroenterol. 2010;28;16(12):1518-1521. doi:10.3748/wjg.v16.i12.1518, PMid:20333794, PMCid:2846259

15. Maehara Y. Alcohol drinking, cigarette smoking, and the development of squamous cell carcinoma of the esophagus. Int J Clin Oncol. 2010;15(2):125 doi:10.1007/s10147-010-0055-8, PMid:20224885

16. Morita M, Kumashiro R, Kubo N, Nakashima Y, Yoshida R, Yoshinaga K, et al. Alcoho drinking, cigarette smoking, and the development of squamous cell carcinoma of the esophagus: epidemiology, clinical findings, and prevention. Int J Clin Oncol. 2010;15(2):126-134. doi:10.1007/s10147-010-0056-7, PMid:20224884 
17. Toh $Y$, Oki E, Ohgaki K, Sakamoto $Y$, Ito S, Egashira A, et al. Alcohol drinking, cigarette smoking, and the development of squamous cell carcinoma of the esophagus: molecular mechanisms of carcinogenesis. Int J Clin Oncol. 2010;15(2):135-144. doi:10.1007/s10147-010-0057-6, PMid:20224883

18. Steevens J, Schouten LJ, Goldbohm RA, Van Den Brandt PA. Alcohol consumption, cigarette smoking and risk of subtypes of oesophageal and gastric cancer: a prospective cohort study. Gut. 2010;59(1):39-48. doi:10.1136/gut.2009.191080 PMid:19828467

19. Kaneko K, Murakami Y, Katagiri A, Konishi K, Kubota Y, Muramoto T, et al. Do daily alcohol and/or cigarette consumption cause low-grade dysplasia, a precursor of esophageal squamous cell carcinoma? I Clin Gastroenterol. 2010;44(3):173-179. doi:10.1097/MCG.0b013e3181bb837a, PMid:19826274

20. Hajizadeh B, Rashidkhani B, Rad AH, Moasheri SM, Saboori H. Dietary patterns and risk of oesophageal squamous cell carcinoma: a case-control study. Public Health Nutr. 2010;13(7):1107-1112. doi:10.1017/S1368980010000145, PMid:20188004
21. Islami F, Ren JS, Taylor PR, Kamangar F. Pickled vegetables and the risk of oesophageal cancer: a meta-analysis. Br J Cancer. 2009;101(9):1641-1647. doi:10.1038/sj.bjc.6605372, PMid:19862003, PMCid:2778505

22. Bahnassy AA, Zekri AR, Abdallah S, El-Shehaby AM, Sherif GM. Human papillomavirus infection in Egyptian esophageal carcinoma: correlation with p53, p21, mdm2, C-erbB2 and impact on survival. Pathol Int. 2005;55(2):53-62. doi:10.1111/j.1440-1827.2005.01804.x, PMid:15693850

23. Lavergne D, De Villiers EM. Papillomavirus in esophageal papillomas and carcinomas. Int J Cancer. 1999;80(5):681-684. doi:10.1002/(SICI)1097 0215(19990301)80:5<681:AID-IJC8>3.3.CO;2-1

24. Wakhisi J, Patel K, Buziba N, Rotich J. Esophageal cancer in north rift valley of Western Kenya. Afr Health Sci. 2005;5(2):157-163. PMid:16006224 PMCid:1831916

25. Chandanos $E$, Lagergren J. The mystery of male dominance in oesophageal cancer and the potential protective role of oestrogen. Eur J Cancer. 2009;45(18):31493155. doi:10.1016/j.ejca.2009.09.001, PMid:19804965 